\section{International Psychiatry Editorial Board}

The Editorial Board of International Psychiatry seeks to expand its membership with the view to enhancing its pool of expertise and managing a wider variety of submission topics. Any informal expressions of interest should be sent to ip@rcpsych.ac.uk. Formal vacancies on the Editorial Board will be advertised in the College e-Newsletter.

\section{RCPsych Awards 2010}

The winners of the second annual RCPsych Awards were announced on 16 November 2010 at a ceremony at the Royal Society of Medicine, hosted by journalist and broadcaster Libby Purves. The awards mark the highest level of achievement within psychiatry, and are designed to recognise and reward excellent practice in the field of mental health.

The winners of the RCPsych Awards 2010 were:

O Lifetime Achievement Award - Professor Sir Michael Rutter

O Psychiatrist of the Year - Dr Michele Hampson

O Psychiatric Academic of the Year - Professor John Geddes

O Core Psychiatric Trainee of the Year - Dr Amanda DerenJones

O Advanced Psychiatric Trainee of the Year - Dr Sharon Smith

O Public Educator of the Year - Dr Max Pemberton

O Specialist Child and Adolescent Mental Health Services Provider of the Year - Flintshire Early Intervention \& Prevention Team and Flintshire Child \& Adolescent Team

O Mental Health Services Provider of the Year - South Staffordshire \& Shropshire Healthcare NHS Foundation Trust

O Psychiatric Team of the Year - Intensive Home Treatment Team, NHS Lothian

O Medical Manager/Leader of the Year - Dr John Simpson. Professor Dinesh Bhugra, President of the Royal College of Psychiatrists, said:

Through the RCPsych Awards, we bring national recognition to those individuals and services who are delivering the highest-quality care for service users and carers, and who are advancing our understanding of mental illness through research and public education. Once again we were overwhelmed by the quality of entries, and our judging panels had an extremely tough job. On behalf of the College, I offer my heartfelt congratulations to the overall winners as well as the outstanding individuals and brilliant teams who were short-listed for each category.

Professor Bhugra paid a special tribute to Professor Sir Michael Rutter, who was presented with the 2010 RCPsych Lifetime Achievement Award. Professor Bhugra said:

Sir Michael has quite simply been one of the most influential psychiatric scientists of his generation. After qualifying in medicine, he embarked on a programme of research and clinical development that transformed child and adolescent psychiatry and, in 1973, became the country's first ever professor of child and adolescent psychiatry. Sir Michael is a richly deserving winner of the RCPsych Lifetime Achievement Award 2010

Nominations for the RCPsych Awards 2011 opened in January. For further details please visit the College website, http://www.rcpsych.ac.uk/events/rcpsychawards2011.aspx

\section{Congratulations to Sheila Hollins}

The House of Lords Appointments Commission announced on 5 October that Professor Sheila Hollins was recommended to be a new non-party-political peer to sit on the crossbenches at the House of Lords. Non-party-political peerages are granted to people of distinction to bring authority and expertise to the House of Lords. The Commission recommends individuals on merit and their ability to contribute effectively to the work of the House. Sheila Hollins is Professor in Psychiatry of Disability at St George's, University of London. Her research has focused on clinical and social aspects of the mental and physical health of people with intellectual disabilities. Since 2008 she has served as the Chair of the World Health Organization's Steering Group to develop a declaration and action plan on the health of children and young people with intellectual disabilities. She has served on a number of national advisory boards, including as a member of the Independent Inquiry into Access to Healthcare for People with Learning Disabilities (2007-08). Professor Hollins was the President of the Royal College of Psychiatrists 2005-08.

\section{Enhancements to the College website}

The contents of the 'College' area of the website have been redistributed. This is part of a wider project to improve overall site navigation and build on the College's reputation for online mental health information. The following areas can now be found in the 'Members' area:

O Public members list

O Divisions

O Special interest groups (SIGs)

O Sections

O Join a SIG or Section

Library and information services

O College archives

Media advice

The following College information pages have been moved to the 'About us' section:

O What we do

O Contact us

O Vacancies 
O Directions to Belgrave Square

O College Officers

O Council structure

O College structure

Equality and diversity

L Legacies and donations

O Interesting RCPsych facts

A new tab called 'Specialties' (http://www.rcpsych.ac.uk/ specialties/faculties.aspx) has been created for Faculties.

\section{New WHO report on mental health and development}

A new report from the World Health Organization (WHO), Mental Health and Development: Targeting People with Mental Health Conditions as a Vulnerable Group (available from http://www.who.int/mental_health/policy/ mhtargeting/en/index.html), calls on all development stakeholders - governments, civil society, multilateral agencies, bilateral agencies, global partnerships, private foundations, academic and research institutions - to focus their attention on mental health. The report presents compelling evidence that persons with mental and psychosocial disabilities are a vulnerable group but continue to be marginalised in terms of development aid and government attention. It makes the case for reaching out to this group through the design and implementation of appropriate policies and programmes and through the inclusion of mental health interventions within broader poverty-reduction and development strategies. The report also describes a number of key interventions which can provide a starting point for these efforts. By investing in persons with mental and psychosocial disabilities, development outcomes can be improved.

\section{Obituary: Haroon Rashid Chaudhry}

It is with great sadness that we inform you of the recent death of Professor Haroon Rashid Chaudhry, Head of the Department of Psychiatry at Fatima Jinnah Medical College, Honorary Executive Director of Fountain House, President of the Pakistan Psychiatric Society, Fellow of the Royal College of Psychiatrists and a member of the International Advisory Board of International Psychiatry. Professor Chaudhry died in Lahore on 5 October 2010, aged 55. A pioneer in bringing psychiatry to general hospitals in Pakistan in the 1960s and an early supporter of rehabilitation programmes in the community, he will be remembered for his contribution to psychiatry and mental health in Pakistan and wider Asia. Deepest condolences go to his family and friends.

\section{Child and adolescent psychiatry training course in Ibadan}

A 1-week intensive course in child and adolescent psychiatry was held in Ibadan, Nigeria, from 11 to 16 October 2010. The course was a collaboration between the West African College of Physicians and the Royal College of Psychiatrists under the memorandum of understanding signed between the two organisations in 2007. The course brought together expertise from both West Africa and the UK and it is hoped will have a significant impact on the child and adolescent mental health services, which are under-resourced in West Africa. It is hoped that this innovative way of delivering joint educational activities will be replicated to provide opportunities for further collaboration between the two organisations.

\section{Loss of the psychiatrist's professional identity}

\footnotetext{
Sir: We read Professor Ikkos's editorial in the October 2010 issue with keen interest. The loss of the psychiatrist's professional identity among patients and colleagues is set to worsen the recruitment crisis facing psychiatry internationally.

The World Psychiatric Association (WPA) has made improving the image of psychiatry and enhancing the quality of psychiatric education its top priorities (Maj, 2008) and, in relation to this, awarded us, at the Royal College of Psychiatrists, a competitive grant to study the aetiology and factors associated with the global recruitment crisis facing psychiatry.
}

A systematic review of the literature has been undertaken to evaluate pre-medical, undergraduate and postgraduate (including societal) factors that affect doctors' career choices in relation to psychiatry. Informed by this review and other expert discussions, an evaluation is now under way in over 20 countries across the world. The study is using a quantitative cross-sectional design, with triangulation of data from questionnaires administered to final-year medical students, together with institutional and national data on selection policy, working conditions, demographics, and recruitment rates. A secondary analysis is of the influence of country, medical school and individual factors upon choosing psychiatry as a career. A full report will be presented to the WPA by July 2011 and the findings will be presented at the World Congress of Psychiatry in Buenos Ares in September 2011. 